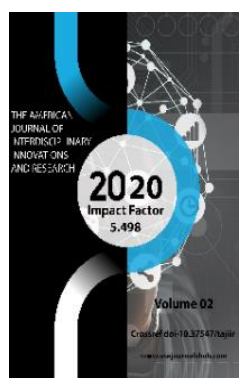

\title{
From The Culture of Labor - To The Culture of Entrepreneurship: A Traditional And Innovative Approach
}

\author{
Lukman Narzullaeyvich Djuraev \\ Doctoral Student, Samarkand State University, Samarkand, Uzbekistan
}

Copyright: Original content from this work may be used under the terms of the creative commons attributes 4.0 licence.

\section{ABSTRACT}

This article shows that through attitude to work, it is required to achieve youthualual and physical perfection, to be fully aware of the scientific, technical and economic foundations of the production processes, and to put in place enormous demands on the organization of vocational training and training in the system of continuous education.

\section{KEYWORDS}

Intellectual and physical, continuous, standard, traditional, labor culture, remuneration, scientific technical.

\section{INTRODUCTION}

At present, the high level of development of technology and technology requires a wide range of computerization of production, the cultural path of development of consumer products at the level of world standards. To do this, it is required to react to Labor and pay an equivalent fee, to achieveualual and physical perfection, to be fully aware of the scientific, technical and economic foundations of the production processes. There are traditional and modern types of labor in the society, which can be traced from the peasant to the service 
sector. This situation dictates the further consideration of the division of Labor, the upbringing of young people who are conscious, creative attitude to Labor. This, in turn, puts enormous demands on the organization of vocational training and training in the system of continuing education. Labor also has its own culture, it forms part of the general culture. The culture of Labor is understood to say that "the level of Organization of production, the adoption of new and effective working methods and communication with colleagues, workers, the search for new ideas, technologies, respect for the property and means of production at its disposal" [1.81]. In order for the emergence of a culture of Labor, to occupy a deep place in the sphere of culture, it is necessary first to carry out Labor Education.

\section{THE MAIN RESULTS AND FINDINGS}

The purpose of Labor Education is to form a conscious attitude to labor in young people. In order to achieve this goal, it is aimed to solve the following tasks positively:

1) formation of the desire and desire to work in young people and their preparation for their activity in various spheres of modern production technology;

2) formation of a sense of labor in the interests of Vatan in young people;

3) development of business skills of young people;

4) continuous improvement of modern knowledge in addition to the existing knowledge of young people;

5) composition of labor skills and skills in youth;

6) culture in youth activity, aspiration to the goal, organization, labor discipline, entrepreneurship, austerity, qualitative performance of work, careful attitude to material wealth, formation of the skills of determining the direction of life activity;

7) to realize that young people, relying on the content of State Policy, seek to acquire professions in accordance with the characteristics of production specific to the regions in which they live;

8) transfer of young people to the profession, introducing them to all kinds of labor activities, as well as specialties that are needed in the area in which they live.

As the main values of economic culture, it is the promotion and legalization of production and entrepreneurial activity that can be conditionally divided into individual elements: labor, property, professional skill, wealth, business and rationality. Let's briefly dwell on all three of these concepts.

Labor is one of the forms of the main values of economic culture, through which the attitude of Man and society to activities on the basis of social life is expressed. Labor as a cultural category is intangible, mavhum consciousness, on the one hand labor is connected with the realization of some material process, on the other hand it is the realization of the ideal.

Labor as a category of entrepreneurial culture involves the management and organization of production, spiritual production is realized as a intellektual work in the field of creativity. The peculiarities of entrepreneurial Labor were studied by the Austrian (later moved to America) scientist Joseph Alois Shumpeter, who showed that the main factor in the development of entrepreneurship is innovation: "...profit, in essence, is the result of the execution of new combinations, without development there will be no profit, without profit there will be no development"[2]. C. A. According to shumpeter, the first basic quality of an entrepreneur is an internally developed intuition that compensates for the lack of information. The second quality is a strong will, traditions, legal and moral norms, which will help to overcome not only the inertia of selfand social thinking, but also the resistance of the environment, etc. The third quality is to offer new combinations of developed imagination that will help and reduce the level 
of uncertainty. Labor has made man become the creator, and material and spiritualproduction spheres in society. In the society carried out the division of Labor into spheres, interpersonal, professional.

Property is not only an economic, legal and political category, but also a reflection of the historically defined way in which people occupy tokens for production and nonproduction purposes.

Thus, the category of property plays the most important role in society. The variety of forms of property and the legal, economic and political emphasis placed correctly in relation to its acquisition should lead to the stabilization of social relations.

Professionalism is the main value of economic culture, closely related to the division of labor in society and reflects its spiritual and moral dimension, the attitude of people towards it. The author of the work"Protestant ethics and the spirit of capitalism" [3.61] M.Weber (18641920) considered entrepreneurship through the category of spirit that is the carrier of entrepreneurship. The entrepreneurial spirit is the sum of all spiritual qualities necessary for success in business. Weber's rational entrepreneurial spirit was tied to religious grounds. He even distinguished such a category as secularism, through which he understood diligence, thriftiness, prudence integrity.

Professionalism today is a feeling of the need to constantly update the already outdated knowledge. In addition to being a master of his profession, updating his field of study means bringing new knowledge into production. Scientists from all over the world pay attention to knowledge as the basis for the development of modern economy. Well-known American sociologist and futurologist $\mathrm{o}$. Toffler wrote that in the XXI century "knowledge becomes the main source for business, because it completely renews the rules of business. As the need for raw materials, untreated material, manpower, time, space and capital slows down, knowledge, property becomes important. Ualual property is a new source of economic development, the value of human knowledge will increase tremendously"[4.669]. Peter Draker " the most expensive asset of any company in the twentieth century was the production of equipment. The most valuable asset of any organization in the 21st century, whether commercial or non-commercial, will be its knowledgeable employees and their productivity"[5.272].

According to the theory of market economy, entrepreneurship is inextricably linked with such a factor as Labor. But entrepreneurship is distinguished as a special factor of production. Because the initial stage of entrepreneurship is associated only with the idea - it is also the result of mental activity, which in the future becomes an enterprise. The activity of an Innovator-entrepreneur is undoubtedly associated with the risk and uncertainty of the success of a business that has already begun. Therefore, it is clear that the solution of such complex and diverse tasks will make much stricter demands on the personal qualities of the entrepreneur himself. Here, knowledge, skills, Ability, Experience, character are important.

The culture of entrepreneurship is a collection of known, established principles, methods, methods of carrying out entrepreneurial activity in accordance with the legal norms (laws, regulations) in force in the country (society), business habits, moral and moral rules, norms of conduct by its subjects, and the implementation of cultured business.

The modern stage of the scientific and technical revolution is associated with the development, implementation and use of the latest technologies. The era of high technologies requires the highest intellektni, developed creativity, which allows the 
entrepreneur to evaluate the economic efficiency of innovations and make a proven decision. Currently, theoretical research focuses not only on entrepreneurship as a method of conducting business on an independent basis, but also on entrepreneurship or corporate internal entrepreneurship within an internal capitalalga based company.

Innovation is becoming the main type of activity in the systems of production and social activity of the present time, expressing the discovery, development and introduction of new ideas, technologies, Information projects and products into society. [6.171]

The culture of Labor unites the culture of production and the culture of management as structural elements (subsystems). The culture of Labor is a collection of these economic values. The culture of production is a collection of values that reflect the level of development of these organizational and technological processes. Management culture is a set of rules that characterize the level of development of management processes in an entrepreneurial structure.

Entrepreneurial activity has a complex, multistage structure as an object of reality. G.V. Clayner noted that the level of observability in socio-economic reality consists of three layers.

The first is a situational layer (data available for experiment, measurement results, statistical data, direct observation and perception).

The second is a phenomenological layer, there are individual elements for observation - these are real ones.

Third-the structural layer, in principle, is not observed, but can be imagined, including socioeconomic structures, mexanizms, trends, too. "Economic methodology ensures the link between economic data, facts and theories and develops links between relevant departments of economic sciencetiradi" [7.61-
70]. Over time, the content of entrepreneurial activity becomes more clear.

In the temporal structure of entrepreneurial activity, stages are distinguished, which consist of stages, which in turn are further divided into stages. In all phases, periods and stages of development, the main features of entrepreneurial activity are manifested. "The entrepreneurial culture development cycle consists of three phases: design, technological and reflexive. The design phase is divided into four stages: 1) conceptual; 2) modeling; 3) constructiv; 4) technological preparation" [8.42]. In the conjectural period, the stage involves the process of identifying the dependent, putting the problem, identifying and finding a solution, setting a goal and selecting criteria. And the modeling period includes the following stages namely construction models, optimization, selection (decision-making). In the constructive period, the activity is divided into the following stages: namely decomposition, Assembly, study of conditions, creation of programs. The choice of stages during the technological preparation period is typical for different types of business and designed systems. In the most general form, it is possible to distinguish the stages of preparation and approval of documents.

The technological phase is divided into the stage of the formation of conditions, the organization of work, the Coordination of work, the delivery and reception of products or the commissioning of an object. Taking into account the peculiarities of the sphere of activity, each of these stages can be divided into more stages.

The reflexive phase includes two stages: the stage of Final Assessment (self-assessment) of the object of entrepreneurial activity (the result obtained) and the stage of Final Assessment (self-assessment) of the subject of entrepreneurial activity). In modern conditions, entrepreneurial activity is carried out in the form of a project. 
A number of definitions have been given to the culture of entrepreneurship as a project. These are understanding as an integral material object; as a natural conditional set of functional interacting components; in the ssifat of a means of solving the problem of entrepreneurship; as a set of components that make up a unit, and as a set of interrelations and interactions of these components with each other and with the external environment. In all of these definitions, entrepreneurship project is defined as a general concept.

In modern conditions, a systematic approach requires researchers to consider all the problems associated with this phenomenon in the study of entrepreneurial culture. A systematic approach to the phenomenon can consist mainly of three positions:

1. Practical systematization of knowledge about the culture of entrepreneurship existing in the Economic Sciences. In this case, it is necessary to regularly review the main theories and approaches that take into account the culture of entrepreneurship.

2. To consider the culture of entrepreneurship as a system consisting of structural elements (subsystems).

3. To determine the role and importance of entrepreneurship culture in different order Systems (Society, National Economic System etc.) (as a small system).

\section{CONCLUSION}

Thus, it is necessary to study the culture of entrepreneurship as an open system, that is, a system that experiences certain influences from systems of higher (lower) levels of complexity.

First, it is worthwhile to present in the transitional society the concept of entrepreneurial culture in a holistic generalized form, based on the relationship of the subjectobject, to develop its structure on various grounds; secondly, it is necessary to conduct a comparative analysis of the entrepreneurial culture of Uzbekistan and foreign countries, determine the level of their development on the basis of cultural and functional approaches, determine the rational and irrational sides, constructive and destructive nature of their transition period;

third, the historical role of socio-cultural determinants in the formation of national models of entrepreneurship was revealed, it was found that the main condition for the formation of a civilization-based entrepreneurial culture is the restoration of traditional socio-cultural values, the formation of directions of national values based on morality and rationalism;

fourth, it is proved that macroeconomic factors in the transitional society play a negative role mainly in the formation of entrepreneurial culture: they form the anomalous state in society, legal nigilism in the entrepreneurial environment;

fifth, it was determined that the formation of a civilization-based entrepreneurial culture implies, first of all, the transformation of the structure of the entrepreneur's motivation on the basis of the rational and economic type of actions carried out in the social and moral worldview;

sixth, the causes and essence of the contradictions in the formation of values of the culture of the young entrepreneur such as individualism, rationalism, freedom were revealed;

seventh, the culture of labor and entrepreneurship are the structural elements of economic culture, combining other elements together with shunning. If the culture of production is a set of values that reflect the level of development of these organizational and technological processes, entrepreneurship is a catalyst that accelerates these processes. 


\section{REFERENCES}

1. Busygin A.V. (2001). Entrepreneurship: 3rd ed. Moscow: Delo.

2. Shumpeter Y. (1990). Theory of economic development: studies of entrepreneurial profit, capital, credit, interest and the cycle of conjuncture. M.

3. Weber M. (1982). Selected works, M.: "Progress".

4. Toffler E. (2003). Metamorphoses of power: trans. from Eng. /E. Toffler. - M.: OOO "Publishing ACT".

5. Drucker, Peter F. (2000). Management challenges for the XXI century.: Per. $s$ angl.:Uch.POS. M.: Publishing house "Williams".

6. Sultanova G.S. (2020). Scientific thinking: innovation and innovation activities. Modern science: new approaches and actual studies, Czech Republic, Prague: Vydavatel "Osvícení», P. 170-173.

7. Kleiner G. (2008). To the dispute about the method: the study of poverty or the poverty of research (on the article By M. Lokshin "Using the scientific method in Russian research in the field of poverty"). Questions of Economics.

8. Levkin N. V. (2009). Development of organizational culture of business structures in the conditions of transformation of the market model of economy: author's abstract. ... d-RA Ekon. Saint Petersburg.

9. Omonov, Q., \& Karimov, N. (2020). Importance Of Ancestoral Heritage. The American Journal of Social Science and Education Innovations, 2(09), 196202.

10. Hayton, J. C., George, G., \& Zahra, S. A. (2002). National culture and entrepreneurship: A review of behavioral research. Entrepreneurship theory and practice, 26(4), 33-52. 